\title{
Determinants of Exchange Rate: Vector Error Correction Method (VECM). Case of Yemen
}

\author{
Ghassan Al-Masbhi, Yulan Du \\ School of Economics and Management, Nanjing University of Science \& Technology, Nanjing, China \\ Email: ghassanalmasbhi@njust.edu.cn
}

How to cite this paper: Al-Masbhi, G., \& Du, Y. L. (2021). Determinants of Exchange Rate: Vector Error Correction Method (VECM). Case of Yemen. Open Journal of Social Sciences, 9, 47-60.

https://doi.org/10.4236/jss.2021.98005

Received: July 4, 2021

Accepted: August 1, 2021

Published: August 4, 2021

Copyright $\odot 2021$ by author(s) and Scientific Research Publishing Inc. This work is licensed under the Creative Commons Attribution International License (CC BY 4.0).

http://creativecommons.org/licenses/by/4.0/

\begin{abstract}
This paper examines the potential determinants of the exchange rate in Yemen. Different econometric tests were applied to examine the impact of the exchange rate on the inflation rate, the current account balance, GDP growth, and interest rate from 1998 to 2020 . Findings show variables are stationary at first difference I(1). Johansen's cointegration test approved the existence of the long-term relationship. According to the VECM test, the variables share a long-run relationship. There is also a short-run association of the exchange rate with inflation and interest rate. The Granger causality test implies that the exchange rate granger causes interest rate and inflation rate. Furthermore, diagnostic tests were performed to check the results' reliability, which shows the findings are consistent. Moreover, the study also suggests that these findings contribute to policymakers and government officials' understanding of the exchange rate fluctuation. It will also show the significant impact of the exchange rate on these variables in Yemen and other developing countries with a similar economic system. The research also provides suggestions to promote development sustainability in Yemen.
\end{abstract}

\section{Keywords}

Exchange Rate, Current Account Balance, Inflation Rate, GDP Growth, Interest Rate, VECM Model

\section{Introduction}

The exchange rate is known as the national currency trade ratio against another foreign currency in the foreign exchange market. It plays a vital role in international trade and is considered an important factor in this globalization era. The exchange rate reflects the national Economy's position. It is accounted as an element of the national monetary system's credibility. It indicates competitive- 
ness in the global Economy and builds up the inner stability for the nation (Lucinda \& Gala, 2006).

The exchange rate is considered one of the most important elements that can contribute to the Economy's stability. It is considered as a component that deals with the development process in high- and low-income countries. The exchange rate contributes to economic development sustainability, leading to improving people's potential in all aspects through education, health, and workplace conditions. A country that enjoys a stable exchange rate tends to be more prosperous and less threatened by hyperinflation and economic crisis.

Exchange rate behavior is considered one of the unsolved issues researchers dealt with. Despite the significance of the exchange rate in any economy, the determinants of it are unsettled. The ambiguity of the study does exist. Additionally, no one can argue against the importance of understanding the leading causes of the exchange rate fluctuation and studying its behavior in detail. Therefore, the research's main objective is to study the exchange rate's determinants represented by interest rate, inflation rate, current account balance, and GDP in Yemen using time series annual data from 1998 to 2020. This paper is constructed into different parts, first is an introduction, second history of literature regarding this study. The third section will mainly shed light on the methodology used in this research. The fourth part will cover the results and discussion of this research, and lastly will be the conclusion.

\section{Case of Yemen}

The Yemeni current exchange rate approach is described as a tightly managed float (Chami et al., 2007). The central bank of Yemen has revealed an implicit desire for stability of Yemeni Rials against the dollar. However, some measure of flexibility is allowed; however, the CBY attempt to avoid day-to-day fluctuations of any magnitude, explaining the Yemeni Rials' $0.01 \%$ average fluctuations per day.

The country has adopted a floating exchange rate system from establishing the economic reform in Yemen in 1996. Yemen's central bank claimed that the fluctuations of the local currency are not economically explained. Yemen's exchange rate has witnessed a continuous increase in the exchange rate from 1996 to 2011 before it drops down for short periods. Such fluctuation harms the Economy; citizens are suffering from the national currency prices that lower living standards. According to the Office for Coordination and Humanitarian Affairs (OCHA, 2018); Over 20 million Yemenis have no access to enough food to maintain health, and 7.4 million are at risk of famine. Therefore, the exchange rate crisis is considered one of the main factors for the collapse of the Economy, leading to the current country's humanitarian crisis.

Figure 1 shows the exchange rate (YER/USD) in Yemen. It can be seen that Yemen's exchange rate is gradually increasing to reach its peak in 2018 with approximately 250 YER/USD. The country's exchange rate was stable from 2011 to 2015 as in that period, Yemen was stabilized politically. However, after 2015, the 


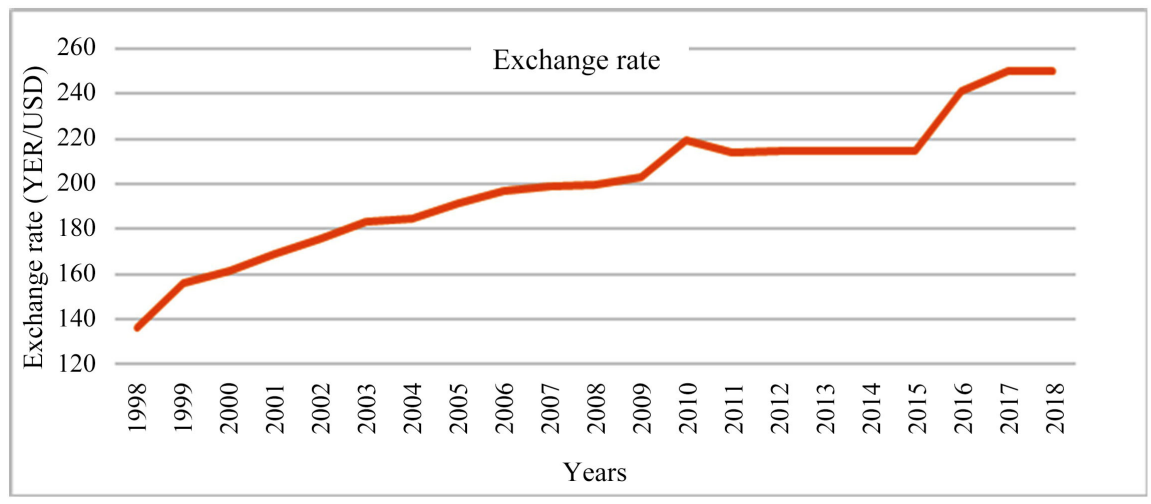

Figure 1. Exchange rate in Yemen.

country went into a civil war that led to a macroeconomic crisis. During this crisis, the commodity supply chain has been severely affected due to restrictions on importation and exportation from/in ports and airports, increasing fuel prices, and prices of goods and services. As a result, a significant increase in the exchange rate was recorded from 2015 to 2018 as shown in Figure 1.

\section{The Objective of This Study and Questions}

Generally, the research will study the effect of the exchange rate on economic variables particularly, the inflation rate, interest rate, current account balance, and GDP growth. By applying econometric models, the research will provide answers to the following questions:

- Does the Exchange rate impact the economic variables (interest rate, inflation rate, Economy growth, and current account balance, and inflation rate) in the long term?

- Does the Exchange rate impact the economic variables (the inflation rate, GDP growth, and current account balance, and interest rate) in the short term?

\section{Literature Review}

The exchange rate fluctuation has a universal impact, with consequences for interest rate, consumer price index (inflation rate) GDP growth, current account balance, and other macro-economic factors. The determinants of exchange rate have been discussed broadly through previous literature. Although many scholars explain the factors that affect the exchange rate volatility, the research regarding this case is considered inconclusive. Additionally, the degree of exchange rate impact on different variables varies from one country to another depending on the Economy's condition. Therefore, this part will mainly discuss the history of varying literature regarding this topic.

\subsection{The Exchange Rate Impact on Interest Rate}

The impact of interest rate on exchange rate have been an interest for investors, countries' authorities and bank managers. The sensitivity of the fluctuation of 
exchange rate to interest rate changes is explained by theoretical models and hypothesis.

When interest rates appreciate, it increases the goods and services prices, decreases the local currency, and enhances the exchange rate volatility. Ahmed and Mazlan (2021) found that there is a short-run relationship between exchange rate and interest rate in ASEAN countries, and interest rate changes negatively affect the exchange rate. Tafa (2015) conducted a study on interest rate's association with the exchange rate. Results indicated that the exchange rate and interest rate are correlated positively in Albania. Gente and Leon-Ledesma (2006) found out that a rise in interest rate impacts the exchange rate by decreasing the home country's currency, which causes an increase in the exchange rate.

Similarly, a study conducted by Hossain and Chowdhury (2014) who studied whether an association between interest rate and exchange rate exists. Findings show a positive relationship between the exchange rate and interest rate. However, Ebiringa and Anyaogu (2014) found a negative relationship between them.

\subsection{The Exchange Rate Impact on GDP Growth}

Wong (2013) studied the relationship between Economic growth and exchange rate by applying the Autoregressive model approach though collecting time-series data for almost four decades. Results showed that the depreciation in the exchange rate value plays a role in the Malaysian Economy's growth. Akram and Rath (2017) carried out a study on the exchange rate misalignment and India's economic growth. Their study revealed a negative association between the variables; an increase in exchange rate leads to a decrease in economic growth and vice versa. They also added that a positive alignment harms the economic growth, and the under-valuation of the exchange rate contributes to economic growth promotion. Besides, Liew et al. (2009) conducted a study of the exchange rate's monetary model using the cointegration technique; their results showed that the exchange rate was negatively affected by the GDP.

\subsection{Impact of Inflation Rate on the Exchange Rate}

Hoang et al. (2020) addressed the impact of exchange rate on inflation. They found out that the exchange rate is positively correlated with the consumer price index in the first quarter and the persistence of past inflation is a factor of the currency fluctuation in Vietnam. Monfared and Akin (2017) carried out a study on the exchange rate and its relationship with inflation rate in Iran. The study applied the VAR model on annual data from 1976-2012. Their findings indicate that there is a correlation between the inflation rate and the exchange rate. By applying the GARCH model, Sek et al. (2012) studied the association between inflation and exchange rate movements. Results concluded that exchange rate volatility shares a positive correlation with the inflation rate. Arghyrou and Pourpourides (2016) carried out a study on inflation's impact on the exchange rate. Results showed that the increased inflation rate leads to a decrease in the home currency value, causing an appreciation in the exchange rate. 
Additionally, Muhammed et al. (2012) studied the exchange rate's effects on the inflation rate. They found out that the inflation rate and exchange rate are positively correlated. Similarly, Reza and Afshan (2017) researched the determinants of the exchange rate. Findings showed a positive correlation between inflation and exchange rate. On the contrary, Necşulescu and Șerbănescu (2013) stated that the Inflation rate negatively correlates with the exchange rate.

\subsection{Impact of Current Account Balance in the Exchange Rate}

Due and Sen (2006) conducted a study on the capital flow volatility and exchange rates. They examined the interactions between exchange rate and current account balance, policies indicators level of capital flows, and fiscal monetary for India's Economy during the period 1993 to 2014. The study results indicate that all variables, including current account balance, are cointegrated, and Granger causes exchange rate. However, Mirchandani (2013) carried out a research on the macroeconomics determinates of exchange rate; his research showed that the exchange rate and current account balance have no relationship. He added that the currency value tends to fall when the current account balance is in deficit and rises when the Current account balance is in surplus.

\section{Methodology}

In this study, several tests are taken to study the determinants of the exchange rate in Yemen. Unit root analysis, ADF test, Johansen Co-integration test, Granger Causality test, and Vector Error Correction Model (VECM). Additionally, diagnostic Checking tests were also performed to check the reliability of the study. An annual time-series data was collected from 1998 to 2018 to examine the determinants of the exchange rate (US \$ as a standard currency). Economic variables are represented by GDP growth inflation rate, interest rate, and current account balance. The data were collected using different databases such as Statista, world bank, economics trading, and index Mundi. The study has a total of 19 observations.

\subsection{Conceptual Framework}

As shown in Figure 2, the study has four independent variables represented by (GDP growth, Current account balance, inflation rate, interest rate) and one dependent variable which is exchange rate.

\subsection{Model Specification}

$$
\mathrm{EXR}_{t}=\beta_{1}+\beta_{2} \mathrm{INF}+\beta_{3} \mathrm{GDP}+\beta_{4} \mathrm{INT}+\beta_{5} \mathrm{CBA}+u_{i}
$$

EXR: Exchange rate (US\$ as standard currency)

INF: Inflation rate

GDP: GDP Growth

INT: interest rate

CBA: Current Account Balance 


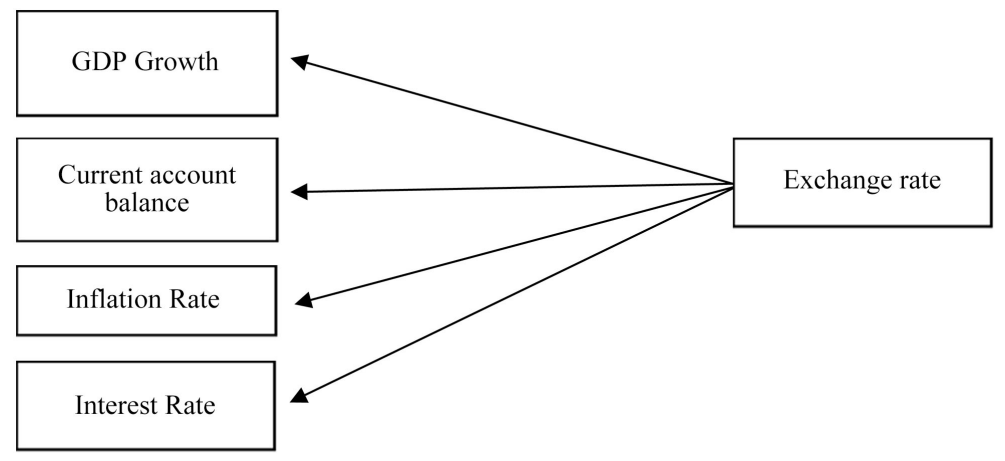

Figure 2. Proposed framework of factors influencing Exchange rate in Yemen from 1998 to 2018.

\subsection{Stationary (ADF Test and pp Test)}

We examine the data's integration and stationarity by using the Augmented Dicky fuller test because the ADF test is more reliable for non-stationary testing data, (Khan, 2013). If the stationarity is not confirmed at Level, first-order differencing should be carried out to achieve the variables' stationarity. The three types of different regression form of ADF are as followed:

1) Without Intercept (c) and Trend ( $t)$ :

$$
Y=\delta Y_{t-1}+u_{t}
$$

2) With Intercept (c):

$$
Y=\alpha+\delta Y_{t-1}+u_{t}
$$

3) With Intercept (c) and Trend (t):

$$
Y=\alpha+\beta T+\delta Y_{t-1}+u_{t}
$$

Before running the analysis and testing for causality, it is important to run the Augmented dicky fuller test and verify the stationarity of the variables. The null and alternative hypothesis are explained as followed:

H0: $\delta=1$ unit root (Variables is not stationary)

H1: $\delta<1$ no unit root (Variable is stationary)

We accept the alternative $\mathrm{H} 0$ and reject the null hypothesis only if the p-value is less than the $5 \%$ significance. Rejection of null-hypothesis, meaning that the variables are stationary and have unit root test.

\subsection{Cointegration Test}

Johansen cointegration test is a multivariate extension where it allows the model to have more than a cointegration vector, it determines if the model is cointegrated using the maximum likelihood approach. The purpose of the cointegration test is to study the long-term association of the dependent and independent variables. The cointegration test is conducted if the variables are stationary at the first difference $\mathrm{I}(1)$ and not at Level $\mathrm{I}(0)$.

\subsection{Vector Error Correction Model (VECM)}

According to Yunus et al. (2014) Vector Error Correction Model is employed to 
identify the movement between the variables. Therefore, VECM is the primary model to study the long-term stable causality between the exogenous and endogenous variables in this research.

General VECM model:

$$
\begin{gathered}
\Delta y_{t}=\beta_{0}+\sum_{i=1}^{n} \beta_{1} \Delta y_{t-1}+\sum_{i=0}^{n} \delta_{i} \Delta x_{t-1}+\varphi z_{t-1}+u_{t} \\
\Delta z_{t-1}=y_{t-1}-\beta_{0}+\beta_{1} x_{t-1}
\end{gathered}
$$

In Equations (2), (3), $\Delta$ represented by the different operator $y_{t}$ refers to the dependent variable $x_{t}$ is the independent variable. $\Delta z_{t-1}$ is the error correction while $z_{t-1}$ is the error term generated by the Johansen cointegration test, $\beta_{0}, \beta_{1}$ and $\delta_{i}$ are the coefficient and $\varphi$ is the coefficient of the error term. $u_{t}$ is the disturbance term.

\subsection{Granger Causality Test}

The Granger causality test is considered a hypothesis test to determine one variable's possibility in forecasting the other, (Gujarati and Porter, 2009). For example, suppose $\mathrm{X}$ granger causes $\mathrm{Y}$. In that case, $\mathrm{X}$ contributes to forecasting $\mathrm{Y}$, which shows the connection that runs from dependent variables to independent ones and vice versa. Therefore, in this study, we use this causality test to determine the relationship between the variables.

\subsection{Diagnostic Checking}

Diagnostic tests such as the Hetersodacity, the Jarque Bera, and Breusch-Godfrey tests are applied to check the model adequacy.

\subsubsection{Hetersodacity}

Hetersodacity is considered a major problem in any regression model since it invalidates the study's model. According to Long and Laurie (1998), heteroscedasticity underestimates the standard error and the variance, making both the $\mathrm{F}$ and $\mathrm{T}$ statistics inaccurate. Therefore, the Heteroskedasticity Test: Breusch-Pagan-Godfrey will be conducted to examine the model's quality of this paper.

\subsubsection{Jarque Bera Test}

Jarque Bera test is based on a large sample and OLS residual tests, Gujarati \& Porter (2009). The Normality is considered an essential test and one of the diagnostic tests that can declare the study's credibility. The normality test helps the test of confidence intervals and significance to become valid. If there is no normality in the regression, the P-values for the overall F-test and T-test will be incorrect. Therefore, the Jarque is introduced to examine the normality and error term in the regression model.

\subsubsection{Auto-Correlation Lm Test}

The autocorrelation is also known as serial or lagged correlation that refers to the correlation degree. This test examines the relationship between past and current values. There are different types of autocorrelation tests; the Durbin Wat- 
son $\mathrm{d}$ and $\mathrm{h}$ test and they are mainly used to examine correlation at first order, while the Breusch Godfrey test examines a higher order of correlation. Therefore, in this study, the Breusch Godfrey is applied in this model.

\section{Discussion and Results}

This part will mainly cover the results of the econometric tests used in this research. The tests employed for this study are as follow; The Dickey Augmented unit root test, Johansen Cointegration Test, and the VECM model. Also, diagnostics tests were performed to check the study's reliability. These tests were performed through statistical software called E-views.

\subsection{Stationary Test (Augmented Dickey Test)}

For cointegration analysis, a stationary test is conducted to examine the availability of unit root to know whether the model is stationary at I(1) or at Level by performing the Augmented Dicky-Fuller test. Table 1 shows the result for the Augmented Dickey Fuller test (ADF). The variables are non-stationary at Level since the $\mathrm{P}$-value is greater than the significant 0.05 . After transforming the data to the first difference, the P-values of the variables (LEX, LBALANCE, LGDP, LINF and LINTER) are less than 0.01 . Therefore, we can reject the null hypothesis declaring that all variables are stationary at $\mathrm{I}(1)$ and there is no unit root.

\subsection{Johannsen Cointegration Test}

The Johansen test is employed to examine the long-term correlation between the dependent variable (LEX) and independent variables (LBALANCE, LGDP, LINF, LINTER). The former test was performed to prove whether variables share a long-run relationship. Results in Table 2 show that both trace statics and the Max-Eigen are rejected at $r=2$; they are cointegrated at $r=2$ at a $1 \%$ significance level. Therefore, this research suggests that there are at least two cointegrations under the null hypothesis.

\section{Vector Error Correction Model; VECM Test}

VECM for long-run relationship

Since our study indicated that there at least 2 cointegrated equations, we can proceed with the VECM model. This model contributes to test the long-run and short-term casualty of the dependent and independent variables. In this study, we have the Exchange rate as a dependent variable while the current account balance, interest rate, inflation rate, and GDP growth are independent variables. After running the VECM test, the result indicates a long-run association between the variables as it shows that the coefficient (C1) is negative and significant. For the long-run relationship coefficient should be negative and the p-value less than the $5 \%$ significant. Table 3 explains the results of VECM in detail.

Cointegration Equation (Long run model):

$$
\begin{aligned}
\text { Ect }_{t-1}= & 1.000 \mathrm{Ex}_{t-1}+8.565 \text { Balance }_{t-1}-3.209 \mathrm{INF}_{t-1} \\
& -1.581 \mathrm{INT}_{t-1}+1.415 \mathrm{GDP}_{t-1}-312.423
\end{aligned}
$$


Table 1. Augmented dicky fuller test.

\begin{tabular}{ccccc}
\hline \multicolumn{4}{c}{ Level } & I(1) \\
\hline Variables & Intercept & Trend and Intercept & Intercept & Trend and Intercept \\
\hline LEX & -1.8695 & -3.4338 & $-4.7586^{* * *}$ & $-4.6507^{* * *}$ \\
LBALANCE & -2.3930 & -2.5645 & $-6.5125^{* * *}$ & $-6.4344^{* * *}$ \\
LGDP & $-3.3031^{* *}$ & -4.0169 & $-4.9591^{* * *}$ & $-4.8101^{* * *}$ \\
LINF & $-2.9693^{*}$ & -4.5688 & $-7.1975^{* * *}$ & $-6.9495^{* * *}$ \\
LINTER & -1.3051 & -2.1686 & $-5.3664^{* * *}$ & $-5.4255^{* * *}$ \\
\hline
\end{tabular}

${ }^{* * *}$ denote that rejection of null hypothesis at 0.01 significant level.

Table 2. Johansen cointegration test.

\begin{tabular}{|c|c|c|c|c|c|c|}
\hline Hypothesis & Trace Statistics & Critical Value & Prop* & Max-Eigen Statistics & s Critical Value & Prop* \\
\hline None & 106.8487 & 69.81889 & 0.0000 & 44.59097 & 33.87687 & 0.0018 \\
\hline At most 1 & 62.25775 & 47.85613 & 0.0013 & 34.46820 & 27.58434 & 0.0056 \\
\hline At most 2 & 27.78956 & 29.79707 & 0.0838 & 13.97149 & 21.13162 & 0.3674 \\
\hline At most 3 & 13.81806 & 15.49471 & 0.0881 & 10.36796 & 14.26460 & 0.1889 \\
\hline At most 4 & 3.450100 & 3.841466 & 0.0632 & 3.450100 & 3.841466 & 0.0632 \\
\hline
\end{tabular}

Table 3. VECM.

\begin{tabular}{ccccc}
\hline & Coefficient & Std.Error & T. Statistics & Probability \\
\hline C $(1)$ & -0.231467 & 0.064053 & -3.613666 & 0.0028 \\
R-squared & 0.778086 & Mean Depend Var & 4.502381 \\
Adjusted R-sqaured & 0.506857 & S.D dependent var & 6.899429 \\
S.E. regession & 4.090612 & Akaike info criteria & 5.916468 \\
Sum squared resid & 234.2635 & Schwarz Criterion & 6.264642 \\
Log-likelihood & -55.12291 & Hannan-Quinn criter. & 5.992031 \\
& & Durbin Watson stat & 1.936347 \\
\hline
\end{tabular}

Furthermore, we notice from equation (7) that $1 \%$ change in the current account balance will result in an $8.56 \%$ decrease in the current account balance. In other words, the Exchange rate shares a negative relationship with the current account balance and GDP growth. In contrast, there is a positive correlation between exchange rate with interest rate and inflation rate.

Results are consistent with a study conducted by Arghyrou and Pourpourides, (2016), who showed that an increase in the inflation rate leads to exchange rate appreciation. Almaw (2020) conducted a research on the determinant of exchange rate and found out that there is a positive correlation of exchange rate with the inflation rate and a negative association with the current account balance. Azid et al. (2005) revealed contradictory results to this study by declaring a 
positive correlation between GDP growth and exchange rate. Additionally, Khan et al. (2019) examined the impact of exchange rates on the macroeconomics variables. They found out that the exchange rate has a positive effect on GDP growth. Simultaneously, it negatively impacts the inflation rate and interest rate, which contradicts this study's results.

\section{VECM model Short-run Casualty (Wald test)}

The wald test was carried to examine the short-run relationship between the variables. Table 4 suggests that there is short-run casualty runs from exchange rate to inflation rate and interest rate. Since the $\mathrm{P}$-value of the variables is higher than $5 \%$ significance, we can conclude that there is NOT a short-run relationship of an exchange rate with GDP growth and current account balance. Shaik \& Rao (2020), with similar results to this study, investigated the impact of exchange rate on economic growth. His results indicated a short-run relationship that runs from exchange rate to inflation rate and interest rate.

\section{Granger-Causality Test}

The causality test is used to find out whether a variable helps in forecasting another. According to Table 5, there are four unidirectional causality relationships among the variables. Results suggest that the current account balance granger causes the exchange rate. Additionally, it can be noticed that the exchange rate contributes to forecast inflation rate and interest rate. Similarly, results also indicate causation that runs from GDP to exchange rate. However, no causation runs from exchange rate to current account balance. Likewise, this study's results are consistent with Khattak et al. (2012), who found out a unidirectional causality between exchange rate and interest rate. Moreover, Reza and Afshan (2017) confirmed the existence of causation that runs from exchange rate to GDP growth.

\subsection{Diagnostic Checking}

Based on EViews, if the P-value is less than the significant Level of $1 \%$ and $5 \%$, we reject the null hypothesis. According to Table 6, we can see that the $p$ values are higher than the significant value 5\%. Therefore, we accept the null hypothesis, which indicates that the model does not suffer from Heteroskedasticity problems. The Jarque-Bera test shows that all residuals are normally distributed since the $p$-value is 0.789693 is greater than the significant $5 \%$. Likewise, Breusch Godfrey test also explains that the model is free from serial correlation. In short, the diagnostic tests that were carried out suggest that all results are reliable and valid.

Table 4. Wald test.

\begin{tabular}{ccccc}
\hline Wald-test results & Current account balance & GDP & Inflation & Interest rate \\
\hline (F-Statistic) & 2.528287 & 1.120704 & $7.861687^{* * *}$ & $6.724973^{\star *}$ \\
Chi square & 2.528287 & 1.120704 & $7.861687^{* * *}$ & $6.724973^{\star * *}$ \\
\hline
\end{tabular}


Table 5. Granger causality test.

\begin{tabular}{cccc}
\hline & Causality Directions & & Results \\
\hline Current account balance & $\rightarrow$ & Exchange rate & Yes, with unidirectional \\
Exchange rate & - & Current account balance & No causality \\
Inflation rate & - & Exchange rate & No causality \\
Exchange rate & $\rightarrow$ & Inflation rate & Yes, with unidirectional \\
Interest rate & - & Exchange rate & No \\
Exchange rate & $\rightarrow$ & Interest rate & Yes, with unidirectional \\
GDP & $\rightarrow$ & Exchange rate & Yes, with unidirectional \\
\hline
\end{tabular}

Table 6. Diagnostic checking.

\begin{tabular}{ccccc}
\hline Test & Hypothesis Ho & T-Stat & $\boldsymbol{P}$-value & Result \\
\hline $\begin{array}{c}\text { Heteroskedasticity Test: } \\
\text { Breusch-Pagan-Godfrey }\end{array}$ & $\begin{array}{c}\text { No } \\
\text { Heteroscedasticity } \\
\text { Jarque-Bera }\end{array}$ & 1.113280 & 0.8922 & $\begin{array}{c}\text { There is no } \\
\text { heteroskedasticity } \\
\text { normally distributed }\end{array}$ \\
Breusch-Godfrey & No serial correlation & 0.589055 & 0.7449 & $\begin{array}{c}\text { No serial correlation in } \\
\text { the model }\end{array}$ \\
\hline
\end{tabular}

\section{Policy Suggestions and Conclusion}

This paper focuses on the Exchange rate determinants taking the case of the Republic of Yemen using annual time series data from 1998-2020. VECM model is applied to investigate the existence of long-run and short-run associations among the variables. Diagnostic tests were also carried out to check the credibility of the study.

VECM model showed a short-term association of the exchange rate with interest rate and inflation rate. Results also show that the exchange rate is positively correlated with inflation and interest rate; additionally, GDP growth and current account balance cause currency depreciation.

The Johansen test for cointegration revealed the presence of a long-term relationship between all variables. Through applying the Granger causality test, it is noticed that there is unidirectional causation that runs from exchange rate to inflation rate and interest rate. Additionally, the GDP growth Granger causes the exchange rate. Moreover, results also show current account balance affects the exchange rate in the long-term and short-term while exchange rate has impacts on inflation rate only in the long run.

Based on the proposed hypothesis, several policies should be enforced to control exchange rate fluctuation, which will solve macroeconomic crisis. The exchange rate in Yemen reflects the economic crisis the country is going through. One of the reasons for the slow economic and development growth in Yemen is the exchange rate instability; the currency's frequent fluctuation affected the country's economy. The stable currency is a good sign for the economic health degree of development and sustainability. Therefore, it is suggested that policy- 
makers in developing countries should pay close attention to the international exchange currency rate. Additionally, it is advised that the government control the country's economic state and balance the money supply to achieve the objectives of lowering inflation rate, growth in aggregate income and solve the unemployment issues. Besides, it is found out that interest rates share a positive association with the exchange rate. In other words, when the interest rate increases, it attracts more foreign capital and causes the exchange rate to rise. Policymakers and the Central bank of Yemen need to control interest rates by lowering the discount rate and improving economic activities. Since the GDP growth helps forecast the exchange rate, it is recommended that Yemen's government sustain a stable exchange rate to enhance Yemen's economic growth.

Furthermore, as an import-dependent country, Yemen should adopt an open economy to international trade as that will ensure to limit the exchange rate fluctuation in a given time by controlling the inflows and outflows of the local and foreign currency. Moreover, the government should directly control macroeconomic variables such as inflation, GDP, and interest rates. Success in this regard will lessen the fluctuation of the exchange rate in the country.

\section{Conflicts of Interest}

The authors declare no conflicts of interest regarding the publication of this paper.

\section{References}

Ahmed, T., \& Mazlan , N. S. (2021). The Impact of Interest Rate on Exchange Rate within ASEAN Countries: Evidence from Linear and Nonlinear ARDL Frameworks. Global Journal of Emerging Market Economies, 13, 7-34. https://doi.org/10.1177/0974910120974798

Akram, V., \& Rath, B. N. (2017). Exchange Rate Misalignment and Economic Growth in India. Journal of Financial Economic Policy, 9, 414-434. https://doi.org/10.1108/JFEP-12-2016-0093

Almaw, S. (2020). Determinant of Exchange rate in Ethiopia: A Graphical Approach. International Affairs and Global Strategy, 84, 7.

Arghyrou, M. G., \& Pourpourides, P. (2016). Inflation Announcements and Asymmetric Exchange Rate Responses. Journal of International Financial Markets, Institutions and Money, 40, 80-84. https://doi.org/10.1016/j.intfin.2015.07.002

Azid, T., Jamil, M., Kousar, A., \& Kemal, M. A. (2005). Impact of Exchange Rate Volatility on Growth and Economic Performance: A Case Study of Pakistan, 1973-2003 [with comments]. The Pakistan Development Review, 44, 749-775. https://doi.org/10.30541/v44i4IIpp.749-775

Chami, S., Todd, S., Faisal, A. and Nabil, B. L. (2007). Yemen: Exchange Rate Policy in the Face of Dwindling Oil Exports. IMF Working Paper 07/5, International Monetary Fund. https://doi.org/10.5089/9781451865691.001

Chowdhury, M., \& Hossain, M. T. (2014). Determinants of Exchange Rate in Bangladesh: A Case Study. Developing Country Studies, 4, 5 p. https://doi.org/10.2139/ssrn.2402908

Due, P., \& Sen, P. (2006). Capital Flow Volatility and Exchange Rates: The Case of India. Working Paper No.144, Central for Development Economics, Department of Econom- 
ics, Delhi School of Economics.

Ebiringa, O. T., \& Anyaogu, N. B. (2014). Exchange Rate, Inflation and Interest Rates Relationships: Autogressive Distributive Lag Analysis. Journal of Economics and Development Studies, 2, 263-279.

Gente, K., \& León-Ledesma, M. A. (2006). Does the World Real Interest Rate Affect the Real Exchange Rate? The South East Asian Experience. The Journal of International Trade \& Economic Development, 15, 441-467. https://doi.org/10.1080/09638190601037443

Gujarati, D. N., \& Porter, D. C. (2009). Essentials of Econometrics (4th ed.). Douglas Reiner.

Hoang, T., Thi, V., \& Minh, H. (2020). The Impact of Exchange Rate on Inflation and Economic Growth in Vietnam. Management Science Letters, 10, 1051-1060. https://doi.org/10.5267/j.msl.2019.11.004

Khan, M. K., Teng, J. Z., \& Khan, M. I. (2019). Cointegration between Macroeconomic Factors and the Exchange rate USD/CNY. Financial Innovation, 5, 1-15. https://doi.org/10.1186/s40854-018-0117-x

Khan, M. T. (2013). Exchange Rate as a Determinant of Fluctuation in Foreign Exchange Reserves: Evidence from Economy of Pakistan. Social Sciences and Humanities, 4, 459471.

Khattak, N. U. R., Tariq, M., \& Khan, J. (2012). Factors Affecting Nominal Interest Rate of Pakistan: An Econometric Investigation. Asian Economic and Financial Review, 2, 421-428.

Liew, V. K. S., Baharumshah, A. Z, \& Puah, C. H. (2009). Monetary Model of Exchange Rate for Thailand: Long-Run Relationship and Monetary Restrictions. Global Economic Review, 38, 385-395. https://doi.org/10.1080/12265080903391784

Long, J. S., \&. Ervin, L. H. (1998). Correcting for Heteroscedasticity with Heteroscedasticity Consistent Standard Errors in the Linear Regression Model: Small Sample Considerations. Working Paper, Indiana University.

Lucinda, C. R., \& Gala, P. (2006). Exchange Rate Misalignment and Growth: Old and New Econometric Evidence. Revista Economia, 7, 165-187.

Mirchandani, A. (2013). Analysis of Macroeconomic Determinants of Exchange Rate Volatility in India. International Journal of Finance \& Economics, 3, 172-179.

Monfared, S. S., \& Akin F. (2017).The Relationship between Exchange Rates and Inflation. European Journal of Sustainable Development, 6, 329-340. https://doi.org/10.14207/ejsd.2017.v6n4p329

Muhammad, J. A., Muhammad, R. S., \& Khadija, T. (2012). Domestic Debt and Inflationary Effects: Evidence from Pakistan. International Journal of Humanities and Social Science, 2, 256-263.

Necșulescu, C. I., \& Șerbănescu, L. L. (2013). Impact of the Inflation on the Exchange Rate and on the Average Salary. International Journal of Cross Cultural Management, 29, 43-48.

OCHA (2018). Crisis Overview. https://www.unocha.org/yemen/crisis-overview

Raza, S. A., \& Afshan, S. (2017). Determinants of Exchange Rate in Pakistan: Revisited with Structural Break Testing. Global Business Review, 18, 825-848. https://doi.org/10.1177/0972150917692210

Sek, S. K., Ooi, C. P., \& Ismail, M. T. (2012). Investigating the Relationship between Exchange Rate and Inflation Targeting. Applied Mathematical Sciences, 6, 1571-1583.

Shaik, K., \& Rao G. B. (2020). Does Exchange Rate Has an Impact on Economic Growth in India? An Empirical Analysis. Theoretical Applied Economics, 27, 223-234. 
Tafa, J. (2015). Relationship between Exchange Rates and Interest Rates: Case of Albania. Mediterranean Journal of Social Sciences, 6, 163.

https://doi.org/10.5901/mjss.2015.v6n4p163

Wong, H.T. (2013). Real Exchange Rate Misalignment and Economic growth in Malaysia. Journal of Economic Studies, 40, 298-313. 40(3), 298-313. https://doi.org/10.1108/01443581311283934

Yunus, M. M., Mahyideen, J. M., \& Saidon, R. (2014). Influences of Macroeconomic Variables on Stock Prices in Malaysia. International Conference on Postgraduate Research, 399-416. 